tive details of administrative and operational problems in CCCs within a large urban area, this needs assessment may assist health professionals in Canada to design and provide a more effective inspection and education program for CCCs.

\section{ACKNOWLEDGEMENTS}

This study is a result of the commitment to more effective services by the former City of Toronto Department of Public Health. The authors wish to thank the infection control team members for their dedication to this project, the staff of the Metro Community Services Department and the Ministry of Community and Social Services for their support and assistance, and Dr. Tim Sly of Ryerson Polytechnic University for reviewing the manuscript.

\section{REFERENCES}

1. Logan R, Belliveau J. Working Mothers. Canadian Social Trends 1995;Spring:25-28.

2. Burke MA, Crompton S, Jones A, et al. Caring for Children. Canadian Social Trends 1991;Autumn:12-15.

3. Thacker SB, Addiss DG, Goodman RA, et al. Infectious diseases and injuries in child day care. JAMA 1992;268(13):1720-26.

4. Holmes SJ, Morrow AL, Pickering LK. Childcare practices: Effects of social change on the epidemiology of infectious diseases and antibiotic resistance. Epidemiol Rev 1996;18(1):10-28.

5. Canadian Paediatric Society. Well Beings: A Guide to Promote the Physical Health, Safety and Emotional Well-Being of Children in Child Care Centres and Family Day Care Homes. Toronto: Creative Premises Ltd, 1992.

6. Bartlett AV, Jarvis BA, Ross V, et al. Diarrheal illness among infants and toddlers in day care centres: Effects of active surveillance and staff training without subsequent monitoring. $\mathrm{Am} \mathrm{J}$ Epidemiol 1988;127(4):808-17.

7. Butz AM, Fosarelli P, Dick J, et al. Prevalence of rotavirus on high-risk fomites in day-care facilities. Pediatrics 1993;92(2):202-5.

8. Fok N, Zazulak E, Mak T. Water Play-Tables in Child Care Centres: Vehicle for Disease Transmission and Control Strategy. Edmonton Board of Health, 1993.

9. Krilov LR, Barone SR, Mandel FS, et al. Impact of an infection control program in a specialized preschool. Am J Infect Control 1996;24:167-73.

Received: September 15, 1997

Accepted: February 13, 1998

Éditorial, de la page 296

tifs. Le travail en partenariat exigera que l'on compose avec les changements en cours et avec les différentes formes d'organisation. Il faut que les chefs de file gardent clairement en vue le système idéal pour pouvoir influencer la réforme dans ce sens. L'objectif final visé doit être celui de préserver et d'améliorer la santé de tous les Canadiens - à savoir de la population

\begin{tabular}{lllllll}
\hline $\mathrm{L}$ & $\mathrm{E}$ & $\mathrm{T}$ & $\mathrm{T}$ & $\mathrm{E}$ & $\mathrm{R}$ & $\mathrm{S}$ \\
\hline
\end{tabular}

\title{
Malaria vs. AIDS: Time to re-evaluate priorities
}

While the World Conference on AIDS cites the devastating toll of this disease last year at 2.3 million deaths, another lesser known but deadly threat to public health simultaneously marches across the globe. One of the world's most common and easily preventable diseases kills 2.7 million people a year. One child dies every 30 seconds from this familiar but forgotten malady: malaria.

With global warming, international travel and drug resistance, malaria is returning with a vengeance. During the 1960 s, malaria was almost eradicated. Malarial deaths in India dipped to zero. Last year 2.85 million Indians contracted the disease. If this doesn't scare you, consider that imported cases in Canada have gone up $70 \%$ over the last three years.

Although the World Health Organization (WHO) is spearheading an assault against malaria, without support from donor countries little progress can be expected. Malaria treatment programs can in fact consume up to $40 \%$ of public health expenditures in some very poor countries. But malaria prevention is actually cheap and easy. Insecticide-treated bednets-that according to $\mathrm{WHO}$ can reduce child mortality by 15 $35 \%$ - cost about $\$ 1.00$. A year's supply of zinc and vitamin A to boost a child's resistance to malaria costs $\$ 1.10$. Education programs, elimination of stagnant water and development of good antimalarial drugs are proven strategies. But funding for antimalarial drug development is currently a paltry $\$ 42.00$ per malarial death compared to $\$ 3,274.00$ per AIDS death.

While AIDS has certainly become the noxious scourge of the 90s, we cannot afford to forgo the fight against some of our planet's oldest plagues. Canada needs to show leadership in the world health community by join- desservie. Ne vous laissez donc pas distraire ni leurrer par les politiques. Avant de permettre aux autres de s'accaparer le contrôle ou d'écarter ce sujet, informez-vous pour pouvoir participer efficacement et proactivement au dialogue. Plus nous comprendrons toutes les possibilités, mieux nous participerons à l'élaboration d'un meilleur système. ing the WHO in stopping the comeback of this stealthy disease.

\section{Karen Hodgson \\ \#2-1121 Collinson Street \\ Victoria, $B C$ V8V $3 C 2$}

The World AIDS conference in Geneva ended on July 3 with cautious indications of increasingly successful treatment. And yet malaria, a far more deadly disease on the rise, kills about 2.7 million people a year with very little fanfare. The direct cost of malaria to African economies approaches $\$ 3$ billion a year and, world-wide, about 500 million people are infected.

The World Health Organization recognizes the danger, but has not yet found a world leader to champion a global campaign against this killer. Perhaps surprisingly, the Canadian government is an excellent candidate to lead the fight. Canada has taken a lead role in international immunization, scored a triumphant success in banning land mines and is actively promoting a world court. Furthermore, there are more cases of malaria in Canada than in the U.S. (1100 vs. 900 cases reported in 1997), despite differences in climate. We have the international credibility and we have a valid reason for a leadership role.

We have also set aside the money. $\$ 90$ million more in foreign aid is promised in next year's budget, with health care the No. 1 priority. A \$10 million annual expenditure on malaria will match the commitment made by the UK's Tony Blair at the G8 summit in May.

In the time you have taken to read this letter, about five people have died from malaria. How much longer should we wait to act?

Randy Rudolph

10319 Street SE, Calgary, $A B$ T2G 3B1 